\title{
2: $28527430-28549167$
}

National Cancer Institute

\section{Source}

National Cancer Institute. 2: 28527430-28549167. NCI Thesaurus. Code C42294.

Physical location of FOSL2_Gene 